\title{
Archæology of Central America*
}

TN default of any statement to the contrary, it is to be assumed that "Contributions to American Archæology" is to serve as a medium of publication for results of the activities of the Carnegie Institution of Washington in American archæological investigation which are not on a sufficiently large scale to justify a separate monograph. The magnitude of an excavation, fortunately, is no gauge of its importance, and although neither of the investigations in the field recorded here proved sensational in its results, each makes a contribution to the archæology of Central America of specific interest, if of limited range.

(1) The excavation of mounds at Baking Pot, British Honduras, by Mr. Oliver Ricketson afforded some interesting, if somewhat obscure, evidence bearing on burial customs under the Mayan 'Old Empire'. The mounds in question, situated about six miles from El Cayo, consist of two groups, lying in a clearing, and each surrounded by innumerable small house-mounds. Of these, Group II. was examined superficially only. Group I. consisted of three small plazas on which were a number of mounds or pyramids. A squarish domeshaped mound and a low platform mound on plaza 3 were the sites of the chief excavation. A fire-pit on plaza 2 was excavated to a depth of two metres by the removal of ashes and small flints showing the effects of intense heat. It was too deep for a cooking-pit and may have served as a crematorium.

On excavation, Mound $G$, the first of the two mounds on plaza 3 , proved to be a burial mound, rectangular in outline with offsets on three sides. An unusual feature was the occurrence of several retaining walls of roughly worked stone on the slopes of the mound. If the top of the mound had once been reached by a stairway on the western slope, obviously the side of approach, it must have been of plaster and had vanished.

Fifteen burials were discovered in that part of the mound which was excavated. The last uncovered was apparently that of a person of importance, as it occupied a stone vault centrally situated in the mound and consisting of rough limestone blocks, the inner faces of which had been smoothed. They had been set in mortar and a cover was formed by limestone slabs, of which the edges had not been trimmed. The dimensions of the chamber, which was at a depth of two metres from the surface of the mound, were two metres in length by $45-50 \mathrm{~cm}$. in width by $50 \mathrm{~cm}$. in height. A narrow shelf of stone extending into the grave on both sides at the bottom reduced the width available for the disposal of the body to not more than $39-42 \mathrm{~cm}$.; but its function was not evident. On the floor of the grave beyond the skeletal remains at head and foot were two black tripod pots.

The skeletal remains were badly preserved and offered little opportunity for examination. The body evidently had been laid on its face. With it were ear plugs and crude beads of jade, shell rosettes, fragments of worked bone, eleven small pieces of iron pyrites, and a number of small fragments of jade, round or in thin plaques.

The other skeletal remains found in the mound were in poor condition, and preservation of anything but fragments was in most cases impossible. Ten skulls were recovered in a condition which permitted of

* Contributions to American Archæology, vol. 1, Nos. 1-4. No. 1 : Fxeavations at Baking Pot, British Honduras, by oliver Ricketson, jr.; No. 2: Maya Astronomy, by Dr. John E. Teeple; No. 3: The Temple of the Wall Panels, Chichen Itzá, by Karl Ruppert; No. 4 Notes on the Metates of Chichen Itzá, Yucatan, by Gustav Stromsvik. (Publication No. 403.) Pp. iii $+157+49$ plates. (Washington, D.C. Carnegie Instutition, 1931.)

No. 3290, Vol. 130] partial examination. Six show fronto-occipital deformation in varying extremes. Five are male, four indubitably female, and one probably female. The average cephalic index is $86 \cdot 37$, six ranging above this average to a maximum of $96 \cdot 8$.

The disposition of fourteen of the burials in the earth of the mound, some within, some without the retaining walls, is suggestive. Four are buried so near the surface and in such relation to one another as to suggest that they were sacrificial victims killed and hurled from the top of the mound and then buried as they lay.

Evidence for dating the site is lacking until the pottery has been more closely examined. Though not an important centre, it was evidently thickly populated at some time-it is suggested, on general grounds, not later than the transition between the Old Empire and the New, say the seventh to eighth century A.D.

(2) The study of the astronomical system of the Mayas has amply repaid the great amount of time and thought that has been spent upon it. The present work brings out the striking fact that the Mayas adopted the position value of numerals, with its necessary adjunct, a sign for zero, at least a thousand years before this step was taken in Europe. Their numerical system, which takes twenty as its base, is now thoroughly understood, and has brought to light the accurate knowledge that the Mayas attained with regard to the heavenly movements. Dr. Teeple gives $365 \cdot 2420$ days as the Maya determination of the length of the tropical year; this is about as accurate as the mean length of the Gregorian year, which is 365.2425 days; the truth lies midway between them; "but the Maya figure was reached a full thousand years before the Gregorian one".

In spite of this knowledge, the Maya appear to have used the 365-day year, letting the seasons drift round it; they also used a second reckoning by 260 -day periods, called tzolkins; thus 73 tzolkins are exactly 52 of their years. No natural period coincides with the tzolkin, but it is very close to three-quarters of the eclipse-year, or interval between successive passages of the sun through the moon's ascending node. The Dresden Codex, the date of which is given as about A.D. 1100 , is concluded to be an eclipse table. The mean length of the lunation was not so well determined as that of the tropical year. Two different values are mentioned, one being a day wrong in two centuries, the other a day in three centuries. Five Venus revolutions (synodic) were taken as equal to eight of their 365-day periods; this is right within a few hours.

Dr. Teeple has made great endeavours to correlate Maya dates with our calendar, but is at present not quite confident of the accuracy of the relation that he gives provisionally, though he has little doubt that the matter will eventually be settled. A hopeful point is that a total eclipse of the sun is calculated to have occurred on July 16, A.D. 790 , on the site of a monument concluded to record an eclipse. The date agrees with Mr. Goodman's correlation.

(3) The excavation of the building since known as "the Temple of the Wall Panels" at Chichen Itzá, was undertaken as a part of the intensive campaign of excavation by the Carnegie Institution on that site. Its specific object was to further the investigation of the fusion of the Nahua and Mayan architectural systems which took place when, in the last 250 years before Chichen Itzá was abandoned in the middle of the fifteenth century, the city reached the height of its glory as a religious centre under alien overlords of 
Mexican extraction. It was in this period that there was an outburst of architectural activity, in which the fundamental conception was Mayan, but the presence of an alion influence is to be soen in serpent columns, sloping lower walls, and othor features.

The Temple of the Wall Panels was chosen for excavation on account of its central position in what is known as the Monjas group. This group would appear to have been the nucleus of the city, as it contains most of the pure Mayan buildings of Chichen Itzá, as well as structures that are doubtful and others that are certainly Nahua. The Temple of the Wall Panels was seen to bo late from the presence of the drums of round columns on the mound; but beyond the fact that it was small, before excavation nothing was to bo seen of its original plan or elevation. When finally cleared, it was found to face west and to consist of a solid pyramidal substructure surmounted by a temple, with a colonnade, forming an integral part of the building, lying directly to the west. 'The entire edifice rests on a terrace reached by two steps. The temple consisted of two chambers, each covered by a vaulted roof. Of the outer facing, little remains. In the debris of the talus on the northern and southern sides were discovered scuiptured stones from panels and mask elements which had fallen from the outer walls. Two warriors are represented on the north panel, one having a long-noso head and an elaborate feathered headdress. The figures are the full height of the panels.

The entrance to the outer chamber is by a triple doorway, 6.71 metres wide, divided by two round columns. Hach chamber has a crudo shrine or altar. In the inner room a beautifully carved stone was discovered, the figures representing warriors.

In excavating the colonnade, of which the roof probably formed the approach to the temple, sculp. tured stones were found which had fallen face down.
They were for the most part in sequence and have been fitted together. They proved to be elements of the pancls of the exterior walls. They were not executed with that fineness of which the Chichen Itzá artists were capable, and it is evident that for detail and finish dependence was placed on the stuceo, of which some still adheres to the stone. These panels are elaborately earved with numerous figures of men and animals.

Certain features justify the assignment of the temple to the Nahua period. These are the colonnade, serpent columns, roof adornos, a battered basal zone, sculptured panels depicting feathered serpents, the acoutre. ments of the warriors, and the sun-disk motive. The Atlantean figures which form part of the Nahua sculptural complex are here represented only in a column drum which had been re-used. This presupposes the building and razing of a structure of Nahua type before the erection of the Temple of the Wall Panels.

(4) The metate or milling stone upon which the pcoples of aboriginal America grind their maize-corn was, and still is, among many of the Indian tribes the most important article of household equipment. Exeept for certain ceremonial examples from Central America, it is normally of simple and purely utilitarian form. This typological stability gives it a peculiar archæological significance, as it is littlo likely to be affected by fortuitous circumstance. It is therefore an admirable source of evidence for certain fundamental groupings. The metutes of Chichen Itzá are considered by Dr. Strúmsvik as falling into a classification of 'heavy grooved type', 'three-legged ungrooved large type', and 'three-legged ungrooved small type'. While suggesting the intrusion of an alien influence, he points to the necessity of more data on the distribution and cultural affinitics of grooved and ungrooved metates in Mexico and Contral America.

\section{The A.I.V. Process of Conserving Green Fodder}

TN these days of economic nationalism and of devalued currency in terrns of gold, it is a cardinal principle to produce as much at home as natural conditions allow. Although only the Dr. Panglosses believe that Great Britain could foed her people entirely and adequately from her own resources, yet all who have studied the question think that we could go a long way towards this goal. Great Britain, for example, is one of the most favoured nations in regard to grass production, yet it imports many million pounds' worth each of butter, cheese, eggs, meat, and concentrated feeding stuffs which could be produced at home. The annual bill for imported concentrated foods is so high that efforts have been made recently to dry artificially the young, protein-rich grass and so conserve it for winter 'keep'. Up to date, experiments made with this object in view in Germany and Great Britain have failed to bring conviction to the economist, and it now looks as if the desired end is to be achieved by a modification of the old practice of ensiling. The ensiling of green fodder crops for use as winter keep has made great headway in New Zealand, the United States, Holland, and Germany, but the English farmer has been slow to realise its advantages. However, he has now an opportunity. Thanks to the enterprise of Imperial Chemical Industries, Ltd., a new chemical method of ensiling, which hails from Finland, has been launched in Great Britain, large-scale experiments having been undertaken at the company's research station at Jealott's Hill, Berks, and at various other places.
When ensilage is made in the ordinary way, in tower, stack, or pit, the greon fodder undergoes various changes, due to enzymes and bacteria, which usually entail a loss of 15-30 per cent of its nutrients, and much more if anything goes wrong with the process, In the new Finnish process-called the A.I.V. process, after the initials of the discoverer, Prof. A. I. Virtunen - such changes are inhibited by maintaining the fodder at a hydrogen ion concentration of 3-4. This is achieved by spraying a dilute acid liquor on to the green crop as it is charged into a pit silo; and mould. growth is prevented by spraying the top layer with an anti-mould preparation, called 'Homesurma' (mould-death). 'The composition of the acid liquor is not revealed, but it is stated to consist mainly of hydrochloric acid, whilst 'Homesurma' is said to consist chiefly of allyl mustard oil. When the pit is fully charged, it must be sealed on the top as tightly as possible, for example, by means of sacking covered with clay or loam, as ingress of air is fatal to success. According to Prof. Virtanen, A.I.V. fodder contains a much higher content of digestible protein than ordinary silage; and he estimates the loss of nutrients in the preparation to be 0.2 per cent from respiration, nothing from decomposition of proteins, and 1.3 per cent from escaped juice.

The A.I.V. process has achieved remarkable success in Finland, where it has been taken up by the butter co-operative export society, Valio, which controls 90 per cent of the butter exported from that country, In 1927 and 1928 , the process was being worked out 